\title{
Psycholinguistic Fundamentals of Non-linearity in Translation
}

\section{Психолінгвістичні основи нелінійності перекладу}

\author{
Marharyta Dorofeieva ${ }^{1}$ \\ Dr. in Philology, \\ Professor \\ Маргарита Дорофесва ${ }^{1}$ \\ доктор філологічних наук, \\ професор \\ E-mail: margarita_dorofeeva@hotmail.com \\ https://orcid.org/0000-0003-2024-4806
}

\section{Anatolii Kotsur ${ }^{2}$}

Dr. in Historical Sciences,

Professor

\author{
Анатолій Коцур² \\ доктор історичних наук, \\ професор
}

E-mail: kotsurap@meta.ua

https://orcid.org/0000-0002-7015-8052

${ }^{1}$ Kyiv National Taras Shevchenko

University, Institute of Philology,

Department of German

Philology and Translation

14, Taras Shevchenko Blvd.,

Kyiv, Ukraine, 01601

${ }^{2}$ Taras Shevchenko National

University of Kyiv

60, Volodymyrska Str., Kyiv,

Ukraine, 01601
${ }^{1}$ Київський національний університет імені Тараса

Шевченка, Інститут філології, кафедра германської філології та перекладу $\triangle$ бульвар Тараса Шевченка, 14, Київ, Україна, 01601

${ }^{2}$ Киівський наџіональний університет імені Тараса Шевченка $\checkmark$ вул. Володимирська, 60, Київ, Україна, 01601

Original manuscript received October 11, 2019

Revised manuscript accepted March 16, 2020 


\section{ABSTRACT}

The article is devoted to the psycholinguistic factors of translation non-linearity, realized in the multiple translation solutions. Multiple solutions are caused by the use of translator's different translation strategies in the same translation situation.

The aim of the study is to identify mechanisms for making translation solutions and to determine psycholinguistic tools to improve the quality of specialized translation.

The research procedure includes a psycholinguistic experiment with the participation of 36 respondents, divided into three groups: the first group 1 - translators with expert status; groups 2, 3 - novice translators with semi-professional translation status. The experiment participants translated a specialized text from German into Ukrainian, in which the number of 13 units carrying informational entropy in relation to the total number of words was 68,0\%. According to the experiment conditions, the participants in group 3 had to additionally perform a pre-translation text analysis (PTA) and a retrospective verbal report (RVR) of their translation solutions.

The results of studying multiple translations of groups 1, 2, 3 and retrospective verbal reports of respondents from group 3 made it possible to establish strategies for translation behavior and ways of making translation solutions according to the procedural scheme. The experimental data showed that translation results of the group 3 in terms of the number of adequate versions (AV) and partially acceptable versions (PAV) were only 6,7\% lower than in the group of professional translators 1. In terms of the number of erroneous versions (EV), group 3 showed only 6,8\% lower translation quality compared to group 1. In group 2, a significantly lower quality of translation was notified. According to the experiment results, in group $233,4 \%$ less AV / PAV was registered, and 35,8\% more EV than in group 1.

The conclusions of the experiment indicate the importance of the psycholinguistic factor of translation solutions' deautomatization at the stages of analysis, synthesis and translation product revision. The psycholinguistic tools of PTA and RVR contributed to improving the specialized translation quality due to the awareness of mental processes by translators.

Key words: non-linearity of translation, translation solution, translation problem, deautomatization, pre-translation analysis, retrospective verbal report.

\section{Вступ}

Традиційний інтерес психолінгвістики до ментальних процесів носія мови та прагнення інтерпретувати мову як динамічну систему мовленнєвої поведінки людини утворює широке міждисциплінарне поле взаємодії з іншими дисциплінами, серед яких чільне місце посідає переклад. Модель процесу перекладу в психолінгвістиці відтворює всі наявні характеристики одномовної людської комунікації з додаванням компонентів, що відбивають когнітивні 
процедури розпізнавання перекладацької проблеми і відповідні стратегії прийняття рішень 3 боку перекладача. Ментальний феномен прийняття рішень все частіше стає об'єктом наукових розвідок психолінгвістичного напряму.

Так, сучасні дослідження в галузі когнітивних наук пропонують експериментальні моделі прийняття рішень, які дозволяють прогнозувати поведінкові та нейрофізіологічні реакції респондентів на момент прийняття рішення, у тому числі за умов множинного вибору (Fechner et al., 2016; Bergner, Oppenheimer \& Detre, 2019). Розглядаючи «ментальний контент» (Nisbett \& Wilson, 1977) процесу перекладу, зарубіжні науковці підкреслюють актуальність не лише розпізнавання конкретних проблем перекладу, а й процесу прийняття перекладацького рішення (Krings, 1986; Segalowitz, Segalowitz \& Wood, 1998; Alves \& Gonçalves, 2013; Chesterman, 2013). У стратегічному контексті прийняття рішень В. Віллс вказує на три системи обмежень, які необхідно враховувати під час виконання перекладу: (1) перекладацьке завдання (формулювання і контекст); (2) текст оригіналу (мовна й дискурсна структури); (3) перекладач (когнітивна система, база знань i професійні навички) (Wills, 2001). Крім того, для формування перекладацької компетентності зазначається необхідність володіння як декларативним, так i процедурним типами знання з боку перекладача (Beeby et al., 2015).

Індивідуально-когнітивні особливості перекладача i сума факторів упливу на процес перекладу, викладені вище, зумовлюють варіативність перекладацьких рішень як результат дії принципу нелінійності перекладу. Нелінійність процесу перекладу реалізується у трьох основних напрямках: (а) відношення до тексту оригіналу як об'єкта перекладу; (б) відношення до структури мислення суб'єкта перекладу; (в) відношення до позамовних факторів навколишньої дійсності (Дорофеєва, 2017b: 332).

Прийняття рішень у процесі перекладу $\epsilon$ надзвичайно складною процедурою, оскільки переклад належить до похідних видів мовленнєвої діяльності (Миньяр-Белоручев, 1996). Це означає, що метою перекладу $\epsilon$ не створення оригіналу, а перетворення останнього у цільовий текст, яке послідовно супроводжується: (а) розпізнаванням перекладацької проблеми; (б) визначенням стратегії рішення проблеми; (в) актом вибору конкретного рішення з боку перекладача. 
Незважаючи на повсякденний характер названих психолінгвістичних операцій, 3 якими стикаються всі перекладачі без виключення, дотепер психолінгвістика перекладу не має однозначної відповіді на питання, які саме психолінгвістичні фактори зумовлюють нелінійність перекладу, які процеси відбуваються на окремих етапах перекладу, а також чи можна вплинути на ці процеси у бік покращення якості цільового тексту.

Відсутність достатньої кількості розвідок у сфері психолінгвістики перекладу, що висвітлюють зв'язок ментальних процесів перекладача 3 варіативністю перекладацьких рішень, визначає актуальність дослідження.

Об’єктом дослідження виступають варіативні перекладацькі рішення як вербалізований результат вибору перекладача.

Предмет розвідки складають психолінгвістичні фактори, що впливають на вибір конкретного перекладацького рішення.

Мета статті полягає у виявленні когнітивних механізмів прийняття перекладацьких рішень суб'єкта під час перекладу, і встановленні психолінгвістичного інструментарію підвищення якості галузевого перекладу. Заявлена мета передбачає вирішення таких завдань: 1) дати визначення понять «нелінійність перекладу», «перекладацька проблема», «перекладацьке рішення» 3 психолінгвістичного погляду; 2) вивчити передумови нелінійності перекладу; 3) виявити психолінгвістичні фактори вибору перекладацького рішення; 4) проаналізувати зв'язок між психолінгвістичними факторами вибору i якістю прийнятого рішення; 5) запропонувати психолінгвістичні шляхи оптимізації прийняття рішень у галузевому перекладі.

Звернімось до експериментальної частини розвідки.

\section{Методи та методики дослідження}

Основні етапи процесу перекладу, а саме: аналіз, синтез і редагування цільового тексту (Bell, 2001; Angelone, 2013), мають психолінгвістичну природу і потребують відповідних методів та інструментів дослідження.

У межах психолінгвістичного й когнітивного підходів перекладознавства процеси перекладу розглядають у двох напрямках. Перший вектор охоплює методи дослідження, орієнтовані 
на продукт перекладу, інструментом яких виступає порівняльний аналіз вихідного та цільового текстів. Такий аналіз проводиться 3 метою встановлення розбіжностей, що непрямо вказують на перебіг мовленнєво-розумових процесів у мозку перекладача під час виконання перекладацького завдання. Другий вектор містить експериментальні методи, орієнтовані на процес перекладу, які здійснюють за допомогою психолінгвістичних методик, у першу чергу, протоколів «міркуй уголос» (ТАР-протоколи), відеозйомки перекладацької поведінки, вимірювання рухів очей протягом читання, заповнення анкет (Jääskeläinen, 2001; Ребрій, 2012, 2014).

Результати застосування обох методів одночасно дозволяють, на нашу думку, отримати більш об'єктивні висновки про особливості обробки інформації на прихованому етапі між розумінням вихідного тексту й породженням цільового тексту у свідомості перекладача. Тому для проведення психолінгвістичного експерименту автор статті обрала комбінований психолінгвістичний метод дослідження, орієнтований як на продукт, так i на процес перекладу, який варіювався у залежності від групи учасників. В експерименті взяли участь три групи досліджуваних.

Першу групу склали учасники семінару підвищення кваліфікації для перекладачів під егідою Австрійського культурного форуму в місті Києві, Інституту філології Київського національного університету імені Тараса Шевченка (КНУ) та Австрійської академічної служби обміну. Семінар проводився при посольстві Австрії в Україні у березні 2015 року. Друга група включала студентів XI семестру Інституту філології КНУ імені Тараса Шевченка спеціалізації 035.043 «германські мови та літератури (переклад включно), перша - німецька», що навчались за освітньонауковою програмою «Германська філологія і переклад (німецька мова та англійська мова)» другого (магістерського) рівня. До третьої групи досліджуваних увійшли студенти VII семестру КНУ спеціалізації 035.041 «Германські мови та літератури (переклад включно), перша - англійська», які навчались за освітньопрофесійною програмою «Переклад 3 англійської та другої західноєвропейської мови» першого (бакалаврського) рівня.

Умови проведення експерименту передбачали неоднаковий рівень мовних знань i перекладацької компетентності всіх учасників експерименту. Так, найвищий рівень експертного статусу мала перша група досліджуваних, яка охоплювала професійних 
перекладачів - викладачів перекладу у базових вищих навчальних закладах України. Друга група належала до непрофесійних перекладачів з високим рівнем мовних знань та напівпрофесійним рівнем перекладацької компетентності, оскільки учасники другої групи навчались у магістратурі за освітньо-науковою програмою, де додатковою спеціалізацією студенти обрали не переклад, а лінгвістику та міжкультурну комунікацію. Третя група складалась iз учасників із потенційно більш низьким рівнем мовних знань $\mathrm{i}$ перекладацької компетентності, а саме - студентів VII семестру бакалаврату 3 англійською як першою, i німецькою як другою іноземними мовами.

Для вивчення результатів перекладу груп 1 i 2 було застосовано метод, орієнтований на продукт, тобто порівняльноперекладацький аналіз вихідного і цільового тексту з урахуванням екстралінгвістичної інформації, наданої у завданні на переклад. Для дослідження варіантів перекладу групи 3 окрім порівняльного аналізу, додатково було застосовано метод RVR (retrospective verbal report), орієнтований на дослідження процесу перекладу - аналіз ретроспективних дослівних записів студентів, зроблених учасниками після виконання перекладу.

Матеріалом експериментального дослідження слугували: 1) фрагмент німецькомовного тексту адміністративно-ділового дискурсу в галузі вищої освіти, що належить до жанру «кодекс ділової етики та поведінки»; 2) варіанти перекладу українською мовою, виконані учасниками експерименту із трьох груп досліджуваних; 3) доперекладацький аналіз і ретроспективні дослівні записи учасників експерименту із групи 3.

Перейдемо до опису проияедури експерименту для кожної 3 трьох груп. Керівник семінару групи респондентів (1) Г. Фляйшманн, викладач Інституту теоретичного і прикладного перекладознавства в університеті імені Карла і Франца м. Грац (Австрія), запропонував учасникам перекласти фрагмент вихідного тексту «Werte- und Verhaltenskodex». Вихідний текст супроводжувався завданням на переклад, яке включало екстралінгвістичну інформацію для доперекладацького аналізу (ДПА) й мала допомогти перекладачам встановити дискурсивно-текстуальні характеристики, компоненти комунікативної ситуації та просторово-часовий фон вихідного тексту. Час виконання завдання на переклад для групи 1 i можливість користуватись допоміжними матеріалами не обмежувались. 
Досліджувані першої групи за попередньою усною згодою та за умови конфіденційності люб'язно надали свої переклади у розпорядження автора статті.

Досліджувані групи 2 - студенти-магістри - отримали ідентичне завдання, але виконували переклад на занятті в аудиторії протягом 90 хвилин, маючи можливість користуватись словниками i допоміжною інформацією з мережі Інтернет.

Умови експерименту для студентів-бакалаврів групи 3 були більш жорсткими у порівнянні 3 групами 1, 2: учасники мали протягом 90 хвилин в аудиторії не тільки перекласти текст, а й виконати письмовий ДПА та здійснити ретроспективний дослівний запис власної перекладацької поведінки, що передувала вибору конкретних перекладацьких рішень. Експеримент у групах 2, 3 проводився під час зимової семестрової атестації 2018-2019 навчальних років.

Загальна кількість учасників експерименту дорівнювала 36 осіб (по 12 учасників у кожній групі досліджуваних). Обсяг тексту, обраного для перекладу, становив 75 слів (675 знаків 3 пробілами). Незначна довжина оригіналу, що складався із трьох розгорнутих речень та заголовка, компенсувалась його структурносемантичною складністю. Так, на семантичному рівні текст налічував 12 повнозначних одиниць перекладу-носіїв інформаційної ентропії (IE), які належали до різних частин мови, а другий абзац тексту, сформований одним реченням довжиною у 39 слів, становив цілісну одиницю IE синтаксичного рівня. Отже, у відсотковому відношенні одиниця макроконтекстного рівня IE дорівнювала 52,0\%, а 13 одиниць IE разом склали 68,0\% від загальної кількості слів у тексті (поняття інформаційної ентропії див. Dorofejewa, 2016).

Вибір тексту 3 високою абсолютною частотою уживання одиниць інформаційної ентропії пояснювався необхідністю вивчення передумов принципу нелінійності перекладу, реалізованого у вигляді різних варіантів перекладу. За гіпотезою автора, одиниці високого ступеня інформаційної ентропії оригіналу є одним із визначальних факторів нелінійності перекладу, а етапи їхньої ревербалізації у варіантах перекладу різних виконавців піддаються спостереженню, аналізу та корекції за допомогою психолінгвістичних методів, орієнтованих на процес перекладу, у нашому випадку через метод ретроспективного дослівного запису. 
Наведімо приклад перекладацького завдання і вихідного тексту для груп респондентів 1, 2 (див. тексти 1, 1.1).

У текстах 1, 1.1. наведені структурні та змістові елементи контрольного завдання для груп досліджуваних 1, 2: завдання німецькою мовою; фрагмент вихідного тексту, призначений для перекладу. Розгляньмо приклад експериментального завдання для групи 3 (див. текст 2).

\section{Текст 1. Angenommener ÜS-Auftrag:}

Die Universität Graz lässt ihren «Werte- und Verhaltenskodex in mehrere Sprachen übersetzen.

укр. гіпотетичне перекладацьке замовлення: університет міста Грац доручив перекласти свій «Кодекс ділової етики» різними мовами.

\section{Текст 1.1. Querschnittsmaterie Gleichstellung}

Chancengerechtigkeit ist als Norm selbstverständlich und im Konsens der Universitätsmitglieder verankert.

Handlungsrelevanz bekommt dieser Konsens erst, wenn den Faktoren proaktiv entgegen gewirkt wird, die die gerechte Verteilung von ZugangsMitgestaltungs- und Aufstiegschancen begrenzen; seien es nur auf bestimmte ForscherInnencharaktere abgestimmte Interaktionen oder Verfahrensweisen, die indirekt Privilegien für bestimmte Gruppen bedeuten.

Das Ziel ist ein Umfeld, in dem Menschen mit unterschiedlichen gesellschaftlichen Hintergründen zur Wissenschaft und den weiteren gesellschaftlichen Aufgaben der Universitäten beitragen können (Werte- und Verhaltenskodex, 2015).

\section{Текст 2.}

1. Nehmen Sie VÜA des Ausgangstextes schriftlich vor.

укр. виконайте письмовий доперекладацький аналіз вихідного тексту.

2. Übersetzen Sie den Text ins Ukrainische (Texte 1, 1.1).

укр. перекладіть текст украӥнською мовою.

3. Wählen Sie drei Übersetzungsschwierigkeiten aus und beschreiben Sie kurz mit Ihren eigenen Worten auf Ukrainisch, wie Sie diese Schwierigkeiten bewältigt haben (retrospektiver wörtlicher Bericht - RVR).

укр. оберіть три перекладаџькі проблеми та коротко опишіть своїми словами украӥнською мовою, як ви їх вирішили.

Текст 2, окрім ідентичного завдання на переклад і вихідного тексту (див. тексти 1, 1.1), містить додаткові завдання для групи 3, пов'язані з самоаналізом розумово-мисленнєвих операцій виконавців під час розпізнавання перекладацької проблеми, на етапі визначення стратегії подолання проблеми, в момент вибору варіанта перекладу, та на подальшому етапі оцінки та/або обгрунтування прийнятого рішення. Перейдемо до аналізу та інтерпретації результатів експерименту. 


\section{Результати та дискусії}

Проблема прийняття перекладацьких рішень виникає тоді, коли з'являється ситуація вибору. Така ситуація може зумовлюватись психолінгвістичними факторами i завжди становить передумову нелінійності перекладу, результатом якої виступають варіативні перекладацькі рішення у паралельних перекладах виконавців. Поняття нелінійності перекладу крізь призму психолінгвістики фактично становить неоднаковий результат вибору перекладача власного перекладацького рішення із можливих альтернатив в однаковій перекладацькій ситуації.

Саме тому дослідження процедур вирішення проблем i прийняття рішень з боку перекладача має виконуватись на базі психолінгвістики. Розгляньмо типові одиниці оригіналу, які зумовили найвищий ступінь нелінійності перекладу за критерієм абсолютної частоти різних варіантів перекладу у паралельних перекладах. До переліку таких лексем на мікроконтекстному рівні оригіналу належали складні іменники з кількома основами: Handlungsrelevanz, Zugangschancen, Mitgestaltungschancen, Aufstiegschancen, ForscherInnencharaktere, Interaktionen, Verfahrensweisen. Оскільки всі перелічені лексеми входять до складу одного речення першоджерела, сконцентруємось на нелінійності макроконтекстного рівня прийняття перекладацьких рішень.

Одиниці нелінійності макроконтекстного рівня охоплювали: 1) заголовок тексту Querschnittsmaterie Gleichstellung; 2) другий абзац у вигляді розгорнутого речення: Handlungsrelevanz bekommt dieser Konsens erst, wenn den Faktoren proaktiv entgegen gewirkt wird, die die gerechte Verteilung von Zugangs-, Mitgestaltungs- und Aufstiegschancen begrenzen; seien es nur auf bestimmte ForscherInnencharaktere abgestimmte Interaktionen oder Verfahrensweisen, die indirekt Privilegien für bestimmte Gruppen bedeuten. На рівні макроконтексту показники нелінійності виявились достатньо високими. Так, варіант перекладу заголовка тексту повторюється лише двічі у 36 учасників, переклад другого речення та/або його смислових частин не $є$ ідентичним у жодній перекладацькій версії (див. зведену табл. 1 далі).

Наведений перелік демонструє одну спільну закономірність: одиниці як семантичного, так і синтаксичного рівня оригіналу мають 
ознаки високого ступеня інформаційної ентропії (багатозначності, граматичної синонімії та жанрової непередбачуваності), що підтверджує гіпотезу автора про інформаційну ентропію як одну 3 передумов нелінійності перекладу.

Розгляньмо нелінійність перекладу макроконтекстного рівня у групах 1-3 на прикладі відтворення заголовка. Хибні переклади позначено символом *, частково прийнятні переклади марковані символом (*) (див. приклад 1).

\begin{tabular}{|c|c|}
\hline \multicolumn{2}{|r|}{ Приклад 1. Querschnittsmaterie Gleichstellung } \\
\hline \multicolumn{2}{|r|}{ Група досліджуваних 1} \\
\hline 1.1. & Рівність залежить в однаковій мірі від усіх (*) \\
\hline 1.2 . & Різноаспектна рівність (*) \\
\hline 1.3 . & Кодекс рівноправності* \\
\hline 1.4. & Принцип рівності можливостей \\
\hline \multicolumn{2}{|r|}{ Група досліджуваних 2} \\
\hline 2.1 . & Ментальний розтин сутності рівноправ’я* \\
\hline 2.2 . & Глобальне питання рівноправності(*) \\
\hline 2.3 . & «Поперечний переріз» рівності* \\
\hline 2.4 . & Рівноправність як наскрізна ідея (*) \\
\hline \multicolumn{2}{|r|}{ Група досліджуваних 3} \\
\hline 3.1 . & Рівноправність (*) як предмет огляду \\
\hline 3.2 . & Рівність у всіх іï проявах (*) \\
\hline 3.3 . & Концепція рівності \\
\hline 3.4 . & Зіставлення основоположних норм* \\
\hline
\end{tabular}

Як бачимо у прикладі 1, жоден із варіантів перекладу заголовка не повторюється. Прокоментуємо причини варіативності перекладацьких рішень. Ситуацію вибору варіанта перекладу формує заголовок фрагмента: Querschnittsmaterie Gleichstellung. Нелінійність відтворення заголовка пов'язана 3 кількома факторами. 3 одного боку, обидва іменники оригіналу включають ознаки одиниць інформаційної ентропії: полісемію, абстрактність, складну структуру. 3 іншого боку, іменник «die Querschnittsmaterie» відзначається не тільки багатозначністю, а й непередбачуваністю для жанру тексту «Кодекс ділової етики». Зрештою, у заголовку має місце нерівномірне співвідношення семантичної та ситуативної інформації. Так, іменник «die Gleichstellung» (укр. «рівність можливостей») вербалізує релевантну семантичну 
інформацію оригіналу на макроконтекстному рівні цілого тексту (інваріант перекладу), водночас семантична інформація іменника «Querschnittsmaterie» дорівнює нулю. Така нерівномірність стає передумовою нелінійності перекладу і становить проблему під час відтворення заголовка у більшості учасників експерименту. Утім, лексема "Querschnittsmaterie» $€$ носієм дискурсивно-ситуативної інформації оригіналу, тому нелінійність (описовість) відтворення цієї інформації не становить проблему для розуміння теми тексту, відтак припускає варіативність перекладацьких рішень (Дорофеєва, 2017с).

У голістичному розумінні синергетики спеціального перекладу фактори впливу на результат включають: 1) фаховий дискурс вихідної мови та лінгвокультури; 2) фаховий дискурс цільової мови та лінгвокультури; 3) фактори комунікативної ситуації, які визначають текст оригіналу; 4) тип тексту оригіналу за перекладознавчою типологією текстів К. Райс; 5) інформаційний запас суб'єкта і адресатів перекладу; 6) вимоги замовника перекладу; 7) когнітивні здатності перекладача, у тому числі ступінь розвиненості перекладацької компетентності; 8) суб'єктивні фактори як умови для виконання перекладу (наявність пошукового інструментарію, фізичний та психологічний стан виконавця) (Дорофеєва, 2017a: 244).

3 погляду психолінгвістики релевантними критеріями вибору рішення з боку перекладача виступають фактори 5, 7, 8. Логічно припустити, що інформаційний запас перекладача i експертний ступінь професійної компетентності вплинуть на якість перекладу у бік іiі покращення, а число адекватних перекладацьких рішень експертів у кількісному відношенні значно перевищуватиме число таких рішень у напівпрофесійних перекладачів. Для перевірки цього припущення необхідно проаналізувати результати вирішення проблем у трьох групах досліджуваних і встановити стратегії поведінки перекладачів. 3 метою визначення стратегій поведінки перекладача, які передують перекладацькому рішенню, доцільно скористатись двома психолінгвістичними інструментами аналізу: (1) процедурна схема прийняття рішення за Р. Корбіном (Corbin, 1980); (2) ретроспективні дослівні записи досліджуваних із групи 3.

Етапи когнітивної процедурної схеми Р. Корбіна, що стосуються прийняття перекладацьких рішень, охоплюють такі 
кроки: 1) ідентифікація (розпізнавання) проблеми перекладу в тексті оригіналу; 2) опис проблеми; 3) збір інформації; 4) виваження рішень; 5) момент вибору; 6) оцінка результатів перекладу (Corbin, 1980: 54). Порівняймо проходження цих етапів на матеріалі обраних ретроспективних дослівних записів процесу перекладу, виконаних досліджуваними із групи 3 (див. приклад 2).

\begin{tabular}{l} 
Приклад 2. Ретроспективний дослівний запис (RVR) \\
виконавця перекладу 3.1 із групи $3^{*}$ \\
\hline Найпершою і найважливішою складністю була назва тексту, яку дуже \\
важливо перекласти правильно, адже вона відображає тему тексту, галузь \\
тощо. Можна легко помилитись при перекладі, якщо розуміти ї̈ буквально і \\
перекладати слова, а не ідею, яку вони передають. Перший переклад терміну \\
«Querschnittsmaterie», який я знайшла, - «січення, розріз». Так як даний \\
фрагмент - з Етичного Кодексу австрійського університету імені Карла і \\
Франца, можна зробити висновок, що текст обрано зі зводу правил, отже, \\
він стосується правових норм. Я вирішила відштовхуватися від другого \\
терміна в назві - «Gleichstellung», тобто «рівноправність», і за асоціативним \\
методом перетворила «розріз матерії» на «предмет розгляду (огляду)» \\
\hline
\end{tabular}

Спробуємо реконструювати хід процесу перекладу на підставі ретроспективного запису у прикладі 2. Виконавиця перекладу розпізнала проблему відтворення заголовка (найпершою $i$ найважливішою складністю була назва тексту - крок 1) i описала проблему (можна легко помилитись при перекладі, якщо розуміти ї̈ буквально і перекладати слова, а не ідею - крок 2). Потім вона зібрала додаткову інформацію для прийняття рішення (перший переклад терміну "Querschnittsmaterie», який я знайшла, «січення, розріз» - крок 3). Далі відбулось виваження рішень на підставі екстралінгвістичної інформації у завданні на переклад та доперекладацького аналізу (можна зробити висновок, щз текст обрано зі зводу правил, отже, він стосується правових норм крок 4). Наступний етап демонструє момент вибору (я вирішила відитовхуватися від другого терміна в назві - «Gleichstellung», тобто "рівноправність», $i$ за асоиіативним методом перетворила «розріз матерї̈» на «предмет розгляду (огляду)»- крок 5). Етап оцінки результатів (крок 6) у наведеному RVR відсутній.

3 нашого боку, можемо констатувати адекватність варіанта перекладу 3.1 у відтворенні дискурсивно-ситуативної інформації (предмет огляду), а також часткову прийнятність у передачі

* Орфографія та стиль виконавця перекладу збережені, запис скорочено 
семантичної інформації, оскільки еквівалентом німецької лексеми Gleichstellung за макроконтекстом та внутрішньою формою виступає не «рівноправність», а словосполучення «рівність можливостей». Розгляньмо інший RVR досліджуваного із групи 3 (див. приклад 3).

Приклад 3. Ретроспективний дослівний запис
виконавця перекладу 3.2 із групи 3*

У прикладі 3 на матеріалі RVR продемонстровано такий перебіг прийняття перекладацького рішення за схемою Р. Корбіна (Corbin, 1980): розпізнавання проблеми (складнощзі при перекладі и̧ього тексту почалися вже з його заголовку - крок 1); збір інформації (із словників стало очевидно, щуо це слово має 2 компоненти крок 3); виваження рішень (тобто мається на увазі питання, яке розглядається з усіх сторін - крок 4); момент вибору (я вирішила перекласти заголовок так: «Рівність в усіх ї̈ проявах»-крок 5). Як бачимо, кроки 2; 6 у RVR виконавця перекладу 3.2 випущені.

У цьому випадку відзначаємо часткову семантичну прийнятність варіанта перекладу 3.2 (рівність), оскільки описовий характер заголовка (в усіх ї̈ проявах) не відповідає жанру тексту і типу фахового дискурсу цільової мови. Проаналізуємо наступний RVR iз групи 3 (див. приклад 4).

\title{
Приклад 4. Ретроспективний дослівний запис
} виконавця перекладу 3.3 із групи $3^{* *}$

\begin{abstract}
Die Querschnittsmaterie - darunter versteht man in der Rechtswissenschaft einen Gegenstand, der von mehreren rechtswissenschaftlichen Fächern bearbeitet wird (укр. die Querschnittsmaterie - це поняття означає в юриспруденції предмет дослідження кількох юридичних дисциплін - переклад наш. - М.Д.) Цей термін був розділений на 2 смислових елемента - я знайшла переклад цих частин; подивилась еквіваленти перекладу в англ. контекстуальному словнику. Ex. Interdisciplinary matter, general matter, cross-cutting element. Обрала генералізований варіант - концепція.
\end{abstract}

\footnotetext{
* Орфографія та стиль виконавця перекладу збережені, запис скорочено

** Орфографія та стиль виконавця перекладу збережені, запис скорочено
} 
На підставі RVR у прикладі 4 спостерігаємо такі кроки процедурної схеми прийняття рішення: збір інформації (Die Querschnittsmaterie - darunter versteht man in der Rechtswissenschaft einen Gegenstand <...> - крок 3); виваження рішень (термін був розділений на 2 смислових елемента $-я<\ldots>$ подивилась еквіваленти перекладу в англ. контекстуальному словнику крок 4); момент вибору (обрала генералізований варіант кониееція - крок 5).

Варіант перекладу заголовка 3.3 можна визнати адекватним як 3 погляду передачі дискурсивно-ситуативної інформації першоджерела (концееція), так і у відтворенні семантичної інформації на рівні макроконтексту оригіналу (концепція рівності). Розгляньмо останній RVR виконавця перекладу 3.4 із групи 3 (див. приклад 5).

Приклад 5. Ретроспективний дослівний запис виконавця перекладу 3.4 із групи $3^{*}$

\footnotetext{
Першою перешкодою у перекладі став заголовок. Я переклав його після перекладу всього тексту. Мій варіант «Зіставлення основоположних норм». Пояснюю чому:

- «Gleichstellung» - порівняння, зіставлення

- Querschnitt - поперечний розріз, тобто те, що показує якусь річ зсередини, а саме іiі основу. Materie - матерія. Слово, яке не вписується в суть взагалі і $є$ дуже загальним. Тому я вирішив брати слово «норма», а саме те, про що йшлося в тексті.
}

Ретроспективний запис перекладача у прикладі 5 «розкладається» на такі кроки прийняття рішень: ідентифікація проблеми (першою перешкодою у перекладі став заголовок - крок 1); збір інформації (я переклав його після перекладу всього тексту крок 3); момент вибору (мій варіант «Зіставлення основоположних норм» - крок 5); оцінка результатів перекладу (Пояснюю чому: < ... Тому я вирішив брати слово «норма», а саме те, про шзо йшлося в тексті - крок 6). Як бачимо, в цьому записі відсутні важливі етапи опису проблеми та виваження рішень (кроки 2; 4), натомість має місце розгорнутий етап 6 - оцінка результату у вигляді обгрунтування обраного перекладацького рішення. Незважаючи на детальне пояснення перекладача, варіант перекладу заголовка 3.4 не можна визнати адекватним. Виконавець неправильно відтворює значення іменника «Gleichstellung» - piвність, обираючи хибний

* Орфографія та стиль виконавця перекладу збережені, запис скорочено 
варіант зі списку галузевих значень у словнику: (Gleichstellung порівняння, зіставлення), а наведений синонім «зіставлення» взагалі не належить до галузевих еквівалентів лексеми Gleichstellung.

Порівняймо результати нелінійності у відтворенні заголовка тексту в окремих групах досліджуваних (див. приклад 1). Отже, в групі 1 зафіксовано 1 адекватний варіант (AВ) - принции рівності можливостей - 1.4; 2 частково прийнятних варіанти (ЧПВ) рівність залежить в однаковій мірі від усіх - 1.1.; різноаспектна рівність - 1.2; та 1 хибний варіант (XВ) перекладу - кодекс рівноправності - 1.3. Кількість адекватних та частково прийнятних варіантів збігається з даними групи 3: 1 AB - конщеециія рівності 3.3; 2 ЧПВ - рівноправність як предмет огляду - 3.1; рівність y всіх іï проявах - 3.2; 1 XB - зіставлення основоположних норм - 3.4.

Дані групи 2 демонструють нижчий рівень якості перекладу заголовка: 2 ЧПВ - глобальне питання рівноправності - 2.2; рівноправність як наскрізна ідея - 2.4; 2 ХВ - ментальний розтин сутності рівноправ'я - 2.1; «поперечний переріз» рівності - 2.3.

Прокоментуємо наведені результати. По-перие, можна помітити, що адекватні варіанти перекладу i частково прийнятні версії у всіх трьох групах групуються за логікою прийняття перекладацького рішення. Шлях (а) ми визначаємо як деконструкцію знаку вихідного тексту у смисл та подальшу генералізовану реконструкцію смислу в абстрактний знак цільового тексту. Прикладами прийняття рішень шляхом (а) слугують варіанти: принцуип рівності можливостей - 1.1; конц̧епцуія рівності 3.3.; глобальне питання рівноправності - 2.2. Тут досліджувані застосовують смисловий переклад і трансформацію генералізації у відтворенні заголовка.

Шлях (б) формулюємо як описову генералізащію та смислову концентрацію ідей. Приклади відтворення заголовка шляхом (б): рівність залежсть в однаковій мірі від усіх - 1.1.; різноаспектна рівність - 1.2; рівноправність як предмет огляду - 3.1; рівність y всіх ї проявах - 3.2; рівноправність як наскрізна ідея - 2.4. Ідучи шляхом (б), виконавці так само користуються смисловим перекладом 3 елементами опису ситуації у формі речень або поширених словосполучень. 
Результати перекладу дозволяють класифікувати i шляхи прийняття хибних рішень перекладачів. По-перше, більшість авторів хибних варіантів у відтворенні заголовка застосовують семантичний паралелізм - шлях (аа). Прикладами обраного шляху (аа) виступають: «поперечний переріз» рівності - 2.3; ментальний розтин сутності рівноправ'я - 2.1; зіставлення основоположних норм - 3.4. На шляху (аа) виконавці використовують знаковий спосіб перекладу і семантичне калькування. По-друге, результати експерименту не підтвердили припущення про значно вищу кількість та якість адекватних перекладацьких рішень у групі експертів 1 порівняно 3 групами напівпрофесійних перекладачів 2, 3. Для унаочнення результатів розгляньмо зведену таблицю кількісних даних нелінійності та якості перекладацьких рішень.

Таблиця 1. Співвідношення абсолютної кількості та якості нелінійних перекладацьких рішень у трьох групах досліджуваних

\begin{tabular}{l|cccccccccc}
\hline Одиниці перекладу & \multicolumn{3}{|c|}{ Група 1 } & \multicolumn{3}{c|}{ Група 2 } & \multicolumn{3}{c}{ Група 3 } \\
\hline Перекладацькі рішення & $\mathrm{AB}$ & ЧПВ & ХВ & АВ & ЧПВ & ХВ & АВ & ЧПВ & ХВ \\
\hline \multirow{2}{*}{$\begin{array}{l}\text { Заголовок } \\
3\end{array}$} & 6 & 3 & 6 & 6 & 6 & 3 & 6 & 3 \\
& 1 & 1 & 0 & 0 & 0 & 0 & 1 & 2 & 0 \\
\hline $\begin{array}{l}\text { Другий абзац } \\
\text { (речення 2) }\end{array}$ & 2 & 4 & 6 & 0 & 4 & 8 & 1 & 4 & 7 \\
\hline
\end{tabular}

Прокоментуємо дані у таблиці 1. Першим доказом того, що результати групи експертів 1 майже дорівнюють результатам групи студентів-бакалаврів 3, виступає кількість адекватних варіантів (AB) та частково прийнятних варіантів (ЧПВ) перекладу. Так, у відтворенні заголовка число $\mathrm{AB}$ в групі 1 збігається з числом $\mathrm{AB}$ у групі 3: 3 правильних варіанти із 12 паралельних перекладів. Те ж саме стосується кількості ЧПВ перекладу заголовка, яка $є$ однаковою у всіх трьох групах $=6$ варіантів. Кількість АВ у відтворенні другого абзацу також не демонструє значних розбіжностей між групами 1, 2 i 3: спостерігається кількісне співвідношення АВ 2: 0: 1. Не менш показовою вважаємо число хибних варіантів (XВ) перекладу в усіх трьох групах. У відтворенні заголовка абсолютна кількість ХВ групи 1 дорівнює кількості ХВ у групі 3: три версії. У групі 2 кількість 
ХВ вища - 6 рішень. Вагомих розбіжностей не спостерігаємо й у відтворенні другого абзацу, кількісне співвідношення ХВ між групами 1, 2, 3 складає 6: 8: 7.

На підставі даних експерименту було встановлено, що переклади групи найнижчого експертного статусу 3 - студентівбакалаврів, які вивчають німецьку мову як другу іноземну, виявились кращими, ніж переклади групи 2, до якої входили студенти другого курсу магістратури 3 німецькою як першою мовою навчання, і майже дорівнювали результатам групи 1 - професійних перекладачів та викладачів перекладу.

Більш висока якість перекладу в групі 3 у порівнянні 3 групою 2 і приблизно однакові показники якості перекладу 3 експертною групою 1 зумовлюється кількома психолінгвістичними факторами. По-перше, умови проведення експерименту в групі 3 передбачали обов'язкове письмове виконання доперекладацького аналізу за відпрацьованою схемою на попередніх заняттях 3 перекладу фахових текстів i ретроспективний дослівний запис етапів прийняття перекладацьких рішень. Такі кроки спричинили, 3 одного боку, деавтоматизацію ментальних процесів аналізу на етапі розпізнавання перекладацьких проблем у вихідному тексті. 3 іншого боку, за допомогою ретроспективного дослівного запису в групі 3 відбулась деавтоматизація процесів синтезу та редагування цільового тексту за принципом негативного зворотного зв'язку. По-друге, фактором деавтоматизації ментальних процесів прийняття перекладацьких рішень виявилась двомовність досліджуваних iз групи 3, які під час перекладу звертались до англомовних паралельних текстів та англо-німецьких словників.

Причини посередньої якості перекладу в групі 1 полягають у високому ступені автоматизації ментальних процесів перекладу, зумовленому сформованими перекладацькими навичками, великим інформаційним запасом i досвідом перекладацької діяльності носіїв експертного статусу. Саме ці когнітивні фактори визначили переважно автоматичний характер стратегій вирішення перекладацьких проблем i пошуку рішень. Водночас така автоматизація через досвід призвела до концентрації уваги на поверхневих структурах тексту і зниження якості перекладу.

Зрештою, негативні результати групи 2, незважаючи на високий ступінь сформованості іншомовної компетентності учасників, пояснюються низьким рівнем розвитку фахових навичок 
перекладу, оскільки в межах філологічно орієнтованої освітньонаукової програми «Германська філологія i переклад» студенти виконують недостатній обсяг вправ на переклад.

\section{Висновки}

1. Нелінійність перекладу з погляду психолінгвістики означає варіативність рішень перекладачів як результат реалізації різних стратегій перекладу, обраних в однаковій перекладацькій ситуації.

2. Перекладацьке рішення в психолінгвістичному аспекті $\epsilon$ результатом перетворення одиниці перекладу вихідного тексту в цільовому тексті на певному рівні ієрархії перекладацьких рішень за принципами від дискурсу до лексеми (Top-down) або від лексеми до дискурсу (Down-top) .

3. Передумовами нелінійності перекладу виступають фактори: (1) когнітивної системи перекладача; (2) структурно-семантичні особливості оригіналу, уживання одиниць інформаційної ентропії (IE) різних рівнів; (3) позамовні фактори, у тому числі умови виконання перекладацького завдання.

4. За результатами експерименту адекватні варіанти і частково прийнятні варіанти перекладу одиниць IE розділено на два напрямки прийняття перекладацьких рішень. У першому напрямку рішення відбувається шляхом деконструкції знаку вихідного тексту у смисл та подальшої генералізованої реконструкції смислу в абстрактний знак цільового тексту. Під час відтворення одиниць IE таким шляхом перекладачі застосовували смисловий спосіб перекладу і прийом генералізації. У другому напрямку прийняття рішення здійснюється через описову генералізацію та смислову концентрацію ідей. У цьому випадку перекладачі також використовували смисловий переклад, але 3 елементами опису ситуації у формі поширених словосполучень або речень.

5. Хибні варіанти перекладу IE об'єднуються за напрямком семантичного паралелізму. На шляху прийняття хибного рішення перекладачі застосовують знаковий спосіб перекладу i прийом семантичного калькування.

6. Психолінгвістичні фактори вибору перекладацького рішення базуються на автоматизації та/або деавтоматизації кроків 
процедурної схеми прийняття перекладацьких рішень. Якість перекладацького продукту в галузевому перекладі залежить від фахової компетентності перекладача за умови деавтоматизацї ментальних процесів аналізу, синтезу та редагування цільового тексту.

7. Усвідомлення ментальних процесів прийняття перекладацьких рішень можливо досягти шляхом застосування комбінації методів класичного перекладознавства та психолінгвістики. На етапі розпізнавання проблеми деавтоматизація відбувається за допомогою доперекладацького аналізу. На етапі синтезу та редагування усвідомлення досягається через інтроспекцію (самоаналіз) під час перекладу та ретроспективний дослівний запис дій перекладача після виконання перекладу.

Перспективою подальших перекладознавчих розвідок $\mathrm{y}$ сфері психолінгвістики вважаємо вивчення співвідношення між ментальними процесами інтуїції, когніції та творчості у спеціальному перекладі.

\section{Література}

Дорофеєва, М.С. (2017а). Синергетика перекладу спецііальних текстів (німецькоукраӥнський напрям). Київ: Видавничий дім Дмитра Бураго.

Дорофеєва, М.С. (2017b). Принцип нелінійності у синергетиці перекладу. Наукові записки, 154, 330-336.

Дорофеєва, М.С. (2017c). Принцип незамкненості у синергетиці перекладу. Філологічні трактати, 8 (1), 47-56.

Миньяр-Белоручев, Р.К. (1996). Теория $u$ методы перевода. Москва: Московский лицей.

Ребрій, О.В. (2012). Сучасні концепиії творчості у перекладі. Харків: ХНУ імені В.Н. Каразіна.

Ребрій, О.В. (2014). Теорія перекладацької творчості у мовному, текстуальному та діяльнісному вимірах. Автореф. дис. д-ра філол. наук. Київ.

Alves, F., \& Gonçalves, J.L. (2013). Investigating the conceptual-procedural distinction in the translation process. Target, 25 (1), 107-124. https://doi.org/10.1075/ target.25.1.09alv

Angelone, E. (2013). The impact of process protocol self-analysis on errors in the translation product. Translation and Interpreting Studies, 8 (2), 253-271. https:// doi.org/10.1075/tis.8.2.07ang

Beeby, A., Castillo, L., Fox, O., Galán Mañas, A., Albir, A.H., Kuznik, A. et al. (2015). Results of PACTE's Experimental Research on the Acquisition of Translation Competence. Translation Spaces, 4 (1), 29-53. https://doi.org/10.1075/ ts.4.1.02bee 
Bell, R. (2001). Psycholinguistic/cognitive approaches. In M. Baker (Ed.), Routledge Encyclopedia of Translation Studies (pp. 185-190). London \& New York: Routledge.

Bergner, A.S., Oppenheimer, D.M., \& Detre, G. (2019). VAMP (Voting Agent Model of Preferences): A computational model of individual multi-attribut choice. Cognition, 192, 103-971. https://doi.org/10.1016/j.cognition.2019.05.008

Chesterman, A. (2013). Models of what processes? Translation and Interpreting Studies, 8 (2), 155-168. https://doi.org/10.1075/tis.8.2.02che

Corbin, R.M. (1980). Decisions that Might not to be Made. In T.S. Wallsten (Ed.), Cognitive Processes in Choice and Decision Behavior (pp. 47-67). Hillsdale, NJ: Erlbaum.

Dorofejewa, M.S. (2016). Entropie der syntaktischen Ebene in der Fachübersetzung. Germanistik in der Ukraine, 11, 159-167.

Fechner, H.B., Pachur, T., Schooler, L.J., Mehlhorn, K., Battal, C., Volz, K.G., et al. (2016). Strategies for memory-based decision making: Modeling behavioral and neural signatures within a cognitive architecture. Cognition, 157, 77-99. https:// doi.org/10.1016/j.cognition.2016.08.011

Jääskelainen, R.H. (2001). Think-aloud-protocols. In M. Baker (Ed.), Routledge Encyclopedia of Translation Studies (pp. 265-269). London \& New York: Routledge.

Krings, H.P. (1986). Was in den Köpfen von Übersetzern vorgeht. Eine empirische Untersuchung zur Struktur des Übersetzungsprozesses an fortgeschrittenen Französichlernern. Tübingen: Narr.

Nisbett, R.E., \& Wilson, T.D. (1977). Telling More than we can Know: Verbal Reports on Mental Processes. Psychological Review, 84 (3), 231-259. https://doi. org/10.1037/0033-295X.84.3.231

Segalowitz, S.J., Segalowitz, N.S., \& Wood, A.G. (1998). Assessing the development of automaticity in second language word recognition. Applied Psycholinguistics, 19 (1), 53-67. https://doi.org/10.1017/S0142716400010572

Wills, W. (2001). Decision making in translation. In M. Baker (Ed.), Routledge Encyclopedia of Translation Studies (pp. 57-60). London \& New York: Routledge.

\section{References}

Dorofeieva, M.S. (2017a). Synerhetyka perekladu spetsialnykh tekstiv (nimetskoukrainskyi napriam) [Synergetics of Specialized Texts Translation (GermanUkrainian direction)]. Kyiv: Vydavnychyi dim Dmytra Buraho [in Ukrainian].

Dorofeieva, M.S. (2017b). Pryntsyp neliniinosti u synerhetytsi perekladu [The principle of non-linearity in translation synergetics]. Naukovi zapysky - Scholarly notes, 154, 330-336 [in Ukrainian].

Dorofeieva, M.S. (2017c). Pryntsyp nezamknenosti u synerhetytsi perekladu [The principle of non-closure in translation synergetics]. Filolohichni traktaty Philological treatises, 8 (1), 47-56 [in Ukrainian].

Minyar-Beloruchev, R.K. (1996). Teoriya $i$ metody perevoda [Theory and methods of translation]. Moscow: Moskovskij licej [in Russian].

Rebrii, O.V. (2012). Suchasni kontseptsii tvorchosti u perekladi [Modern Concepts of Creativity in Translation] Kharkiv: KhNU imeni V.N. Karazina [in Ukrainian]. 
Rebrii, O.V. (2014). Teoriia perekladatskoi tvorchosti u movnomu, tekstualnomu ta diialnisnomu vymirakh [Theory of Translation Creativity in Linguistic, Textual and Activity Dimensions]. Extended abstract of Doctor's thesis. Kyiv [in Ukrainian].

Alves, F., \& Gonçalves, J.L. (2013). Investigating the conceptual-procedural distinction in the translation process. Target, 25 (1), 107-124. https://doi.org/10.1075/ target.25.1.09alv

Angelone, E. (2013). The impact of process protocol self-analysis on errors in the translation product. Translation and Interpreting Studies, 8 (2), 253-271. https:// doi.org/10.1075/tis.8.2.07ang

Beeby, A., Castillo, L., Fox, O., Galán Mañas, A., Albir, A.H., Kuznik, A. et al. (2015). Results of PACTE's Experimental Research on the Acquisition of Translation Competence. Translation Spaces, 4 (1), 29-53. https://doi. org/10.1075/ts.4.1.02bee

Bell, R. (2001). Psycholinguistic/cognitive approaches. In M. Baker (Ed.), Routledge Encyclopedia of Translation Studies (pp. 185-190). London \& New York: Routledge.

Bergner, A.S., Oppenheimer, D.M., \& Detre, G. (2019). VAMP (Voting Agent Model of Preferences): A computational model of individual multi-attribut choice. Cognition, 192, 103-971. https://doi.org/10.1016/j.cognition.2019.05.008

Chesterman, A. (2013). Models of what processes? Translation and Interpreting Studies, 8 (2), 155-168. https://doi.org/10.1075/tis.8.2.02che

Corbin, R.M. (1980). Decisions that Might not to be Made. In T.S. Wallsten (Ed.), Cognitive Processes in Choice and Decision Behavior (pp. 47-67). Hillsdale, NJ: Erlbaum.

Dorofejewa, M.S. (2016). Entropie der syntaktischen Ebene in der Fachübersetzung. Germanistik in der Ukraine, 11, 159-167.

Fechner, H.B., Pachur, T., Schooler, L.J., Mehlhorn, K., Battal, C., Volz, K.G., et al. (2016). Strategies for memory-based decision making: Modeling behavioral and neural signatures within a cognitive architecture. Cognition, 157, 77-99. https:// doi.org/10.1016/j.cognition.2016.08.011

Jääskelainen, R.H. (2001). Think-aloud-protocols. In M. Baker (Ed.), Routledge Encyclopedia of Translation Studies (pp. 265-269). London \& New York: Routledge.

Krings, H.P. (1986). Was in den Köpfen von Übersetzern vorgeht. Eine empirische Untersuchung zur Struktur des Übersetzungsprozesses an fortgeschrittenen Französichlernern. Tübingen: Narr.

Nisbett, R.E., \& Wilson, T.D. (1977). Telling More than we can Know: Verbal Reports on Mental Processes. Psychological Review, 84 (3), 231-259. https://doi. org/10.1037/0033-295X.84.3.231

Segalowitz, S.J., Segalowitz, N.S., \& Wood, A.G. (1998). Assessing the development of automaticity in second language word recognition. Applied Psycholinguistics, 19 (1), 53-67. https://doi.org/10.1017/S0142716400010572

Wills, W. (2001). Decision making in translation. In M. Baker (Ed.), Routledge Encyclopedia of Translation Studies (pp. 57-60). London \& New York: Routledge. 


\section{АНОТАЦІЯ}

У статті розглядаються психолінгвістичні фактори нелінійності перекладу, яка реалізується у множинності рішень перекладачів. Множинність рішень зумовлено застосуванням різних перекладацьких стратегій суб'єктами перекладу в однаковій перекладацькій ситуації. Дослідження має на меті виявити когнітивні механізми прийняття перекладацьких рішень й установити психолінгвістичні інструменти підвищення якості галузевого перекладу.

Процедура дослідження включає психолінгвістичний експеримент за участю 36 респондентів, поділених на три групи: група 1 - перекладачі з експертним статусом; групи 2, 3 - початківці з напівпрофесійним статусом. Учасники експерименту переклали німецький галузевий текст українською мовою, в якому кількість 13 одиниць-носіїв ентропії у відношенні до загальної кількості слів становила 68,0\%. За умовами експерименту учасники групи 3 мали додатково виконати доперекладацький аналіз (ДПА) та ретроспективний дослівний запис (RVR) обраних перекладацьких рішень.

Результати вивчення варіантів перекладу в групах 1, 2, 3 та ретроспективних дослівних записів групи 3 дозволили встановити стратегії перекладацької поведінки й шляхи прийняття перекладацьких рішень за процедурною схемою. Дані показали, що результати перекладу групи 3 за кількістю адекватних варіантів (AB) та частково прийнятних варіантів (ЧПВ) виявились лише на 6,7\% нижче, ніж в групі 1. За кількістю хибних варіантів (ХВ) група 3 продемонструвала лише на 6,8\% нижчу якість перекладу порівняно з групою 1. В групі 2 заріксовано значно нижчу якість перекладу. За даними експерименту в групі 2 зареєстровано на 33,4\% менше АВ/ЧПВ, та на 35,8\% більше ХВ, ніж в групі 1.

Висновки експерименту свідчать про значущість психолінгвістичного фактору деавтоматизації процесів прийняття перекладацьких рішень на етапах аналізу, синтезу та редагування тексту перекладу. Психолінгвістичні інструменти ДПА ma RVR виявились засобами підвищення якості галузевого перекладу через усвідомлення ментальних перекладацьких процесів з боку перекладачів.

Ключові слова: нелінійність перекладу, перекладацьке рішення, проблема перекладу, деавтоматизація, доперекладацький аналіз, ретроспективний дослівний запис.

\section{Дорофеева Маргарита \& Кочур Анатолий. Психолингвистические основы нелинейности перевода}

\section{АННОТАЦИЯ}

В cтатье рассмотрены психолингвистические фракторы нелинейности перевода, реализующиеся во множественности решений переводчиков. Множественность решений обусловлена применением различных переводческих стратегий субъектами перевода в одинаковой переводческой ситуации. Целью исследования является обнаружение механизмов принятия переводческих 
решений в аспекте психолингвистики и выявление психолингвистических инструментов повышения качества специального перевода.

Процедура исследования включает психолингвистический эксперимент с участием 36 респондентов, разделенных на три группы: группа 1 переводчиков со статусом эксперта; группы 2, 3 начинающих переводчиков с полупрофессиональным переводческим статусом. Участники эксперимента выполнили перевод с немецкого на украинский язык специального текста, в котором количество 13 единиц-носителей информационной энтропии по отношению к общему количеству слов составило 68,0\%. По условиям эксперимента участники группы 3 должны были дополнительно выполнить предпереводческий анализ текста (ППА) и ретроспективную дословную запись (RVR) принятых переводческих решений.

Результаты изучения множественных переводов групп 1, 2, 3 и ретроспективных дословных записей респондентов группы 3 позволили установить стратегии переводческого поведения и пути принятия переводческих решений по процедурной схеме. Данные эксперимента показали, что результаты перевода группы 3 по количеству адекватных вариантов (AB) и частично приемлемых вариантов (чПВ) оказались всего на 6,7\% ниже, чем в группе профрессиональных переводчиков 1. По количеству ошибочных вариантов (OB) группа 3 продемонстрировала всего на 6,8\% более низкое качество перевода по сравнению с группой 1. В группе 2 зафиксировано значительно более низкое качество перевода. По результатам эксперимента в группе 2 зарегистрировано на 33,4\% меньше $A B / 4 П В$, и на 35,8\% больше OB, чем в группе 1.

Выводы психолингвистического эксперимента свидетельствуют о значимости психолингвистического фрактора деавтоматизации процессов принятия переводческих решений на этапах анализа, синтеза и редактирования текста перевода. Психолингвистические инструменты ДПА и RVR способствовали повышению качества специального перевода благодаря осознанию ментальных переводческих прочессов со стороны переводчиков.

Ключевые слова: нелинейность перевода, переводческое решение, проблема перевода, деавтоматизация, предпереводческий анализ, ретроспективная дословная запись. 